\title{
University - Enterprises Cooperation Via Incubation Process
}

\author{
Aureo C. Ferreira; Carlos A. Schneider \\ GRUCON - Mechanical Engineering Department/ \\ CERTI - Mechanical Engineering Department/ \\ Universidade Federal de Santa Catarina - Po box. 476 \\ 88040-900 - Florianópolis/SC - Brazil \\ Tel. 55-482-319387/319349 Fax. 55-482-341519 \\ email:acf@grucon.ufsc.br
}

\begin{abstract}
In the past the Brazilian Universities had little or practically none integration with enterprises. The main reasons for this lack of cooperation were usually related to the excess of theory in the class room, in detriment of the rapid use of this theory in real applications, as well as due to the hunger of the enterprises for immediate results in terms of profit. In the beginning of the high technology boom, when the air-space race started, only selected research institutions and large size enterprises, from developed countries, had possibilities to experience the cooperation in this sophisticated and very expensive field, where a large amount of money was invested resulting, not only in high political prestige for the governments of the involved countries, but also in a large number of new products and technologies that where incorporated to the common human life, resulting in several well known benefits ( the telecommunications area is just one example).The main objective of this paper is to give an introduction to the meaning of Enterprises Incubation as well as to report two experiences of its application to high technology small size enterprises creation in Florianópolis, Brazil, where a strong cooperation among university, entrepreneurs association, local government and hi-tech researchers led to successful results improving the performance of start ups.
\end{abstract}

\section{Keywords}

Incubation; SMS Enterprises; Cooperation; High Technology

\section{INTRODUCTION}

The creation and consolidation of an authentic high technology product and service supplying enterprise, innovative and competitive, is rare. Nevertheless, the modernization of the product 
process would be, at least, very difficult, or even not viable, without the contribution of these specialized enterprises, usually of small and medium size(SMSE).Its creation and development may be stimulated, under low cost conditions and achieving a high degree of success, via the mechanism of Enterprise Incubator [01].

The incubation process of Technology Based Enterprises(TBEs) is today one of the most dynamic and efficient way to promote the technological innovation process of the industry and to make real the so desired university-enterprise integration.

Worldwide, this phenomenon of generation and support to TBEs, via incubators, is being intensively disseminated and strengthened. One of the early evidences of an incubator appeared at Stanford University, in the Silicon Valley [03], becoming the origin for a series of new and vigorous TBEs settlement on that region, that is today one of the most important Technological Poles all over the world. According to the National Business Incubator Association there are more than 500 Incubators (from these 300 are TBEs) in USA.

A Technologic Based Enterprise Incubator(TBEI) is not only a condominium building where several neophyte enterprises have an exclusive space(module) and share other spaces, like infrastructure and basic services. A TBEI is a laboratory that must be conducted knowing several factors that are in favor and against the success of an enterprise. It is essential to use modern management and production techniques, as well as the support of scientific and technological knowledge, in accordance with the enterprise reality. The result must be a competitive enterprise, integrated in the market and having economic capacity, to face the investments, when leaving the incubator after 2 to 5 years(at the latest ).

The TBEs require high qualified manpower and technology derived from innovative technical/scientific research. The access to information is also essential to assure that the productive process is update, either via bibliography or specialized consulting.

Human resources, technology and information, with quality, are not easy to find in underdeveloping countries where, usually, they are only available in universities, research and technological centers and in large enterprises that invest in R\&D. Thus, it is natural, specially during economic recession periods, that TBEs look for a place, to install their infrastructure, close to these "know how/why sources", in the space provided by the incubators, for instance.

There are two types of incubators: using partnership or the university. In the last one, the incubator is entirely integrated to the environment of the university, giving to the entrepreneur the opportunity to use the university labs infrastructure, as well as other facilities of the campus, for the development of the technology, the prototype, the production process and the business plan, promoting and supporting the enterprise generation up to the phase just before its entrance in the market.

The partnership incubator may be installed either inside or outside of a university campus, staying certainly, as close as possible, to the main "know how/why source". It is called partnership because the support usually comes from a joint effort of the local government entrepreneur associations, technical schools, universities and others. In this type of incubator, the central objective is the enterprise development related to the production, its introduction in the market and its economical as well as technological strengthening.

The success of the TBEs incubation process depends, in large, on the infrastructure conditions, the environment conjuncture, the innovation sources, the entrepreneurs themselves and, naturally, on the market receptivity. The management of an incubator must be done in a conscious way, having the dominion of the "Business Paradigm", a model that is being developed in accordance to the Latin-American peculiarities, by Prof. William Bolton, from Cambridge, in the scope of the Columbus Project activities[02]. 
The level of the investment return, from a TBEI, is quite high when there are: knowledge about the process, efforts union, independence and administrative austerity.

For the University, the Incubator success represents a technical-scientific challenge and an excellent opportunity for a financial return. Nevertheless, it is necessary a conscious and careful work in order to push the Incubators to become an efficient channel for technology transfer from the University to the society, obviously with a multiplier effect in benefit of the regional and national development.

More details will be presented in the description of the two experiences and in the conclusions.

\section{THE CERTI EXPERIENCE}

The CERTI Foundation - Regional Center of Technology in Informatics of Santa Catarina[01], a private entity settled in Florianópolis (south region of Brazil), without profit objectives, was created in 1984 having the mission to "create technological solutions to lead their clients to reach the world class of high quality". During the first ten years the activities of CERTI were concentrated mainly in the areas of metrology, instrumentation and industrial automation, in a close cooperation with the Mechanical Engineering and others Departments of Federal University of Santa Catarina(UFSC). In 1986, motivated by the declared interest, of government and association entities, in stimulating the economic development of Florianópolis and surroundings, some how to arise Technologic Based Enterprises, CERTI has created (with the partnership of the Province Government) the Technological Empresarial Incubator (TEI).

As a consequence of this process, it was started in 1990, in Florianópolis, an institutional development process leading to the creation of TECNOPOLIS - Technological Pole of Florianópolis and Surroundings - a regional development policy based on the support to the arising and development of TBEs. Another consequence of the same process was the inauguration of the Technological Park ALFA, having an area of $100,000 \mathrm{~m}^{2}$, with 13 modules to receive the new TBEs in a building area of approximately $25,000 \mathrm{~m}^{2}$, including the Incubator.

Along these 9 years of work the TEI has already accumulated a good experience on the Management of the Incubation Process of TBEs as it is demonstrated in the following numbers:

- 6 Consolidated TBEs already left TEI;

- 6 Consolidated TBEs bought modules in Technological Park and are already there;

- 15 Consolidated TBEs are occupying an area of $1400 \mathrm{~m}^{2}$;

- More than 1500 people had already visited the TEI since 1986

- It is constant the cooperation with other Brazilian and European incubators (specially Holland, England and Germany)

This incubation process has been intensively studied and discussed, nationally as well as internationally, aiming to achieve the best results related to:

- mortality rate of the enterprises

- intensity of the generation of technological innovation 
- number of working places generated

- enterprises growing rates

- strategic importance of TBEs created for the regional and/or local development

- income and taxes of the enterprises

- influence of the incubator in the enterprising culture of the region

In general, the management of the TBEs incubation process, means to manage a set of process that, happening along the incubation enterprise "life", influence the results of the above mentioned indicators. The main process involved are:

- TBEs selection

- TBEs support and follow-up

- TBEs evaluation

- TBEs training and improvement

- Support to the activities for technology transfer

- Helping TBEs in the searching for financial support

- Relationship with technical partners of TBEs

- The every day management of the Incubator

- Marketing and divulgation of the incubator

- Interaction with governmental and other entities

The management of such process ask for a certain knowledge, today called "Technology of the Incubator Process", that may only be dominated via permanent contact and interaction with the TBEs, in order to identify and supply adequately their necessities. Like any other process, the Incubation must achieve adequate performance levels, this means it needs to have Total Quality.

In 1991 CERTI started an action line in Quality Management as a result of several contacts with associated enterprises that were looking for a support in management technologies, besides the traditional technological solutions aiming to improve the product development process. A Quality Management Group was created under the coordination of a consulting expert in Total Quality Control Management(TQM) implementation. Up to now more than 35 clients had TQM projects been implemented in their enterprises.

Based on these two experiences (TEI administration and the action on TQM), in 1993 CERTI started to work in the integration of these two areas, aiming to implement a TQM program to improve the incubation process of TBEs.

In a first phase, two TBEs enterprises have integrated a group of 9 enterprises in a SPQM (Specialization Program in Quality Management) partially supported by the Brazilian Science and Technology Ministry and FINEP (Brazilian Financing Agency of Studies and Projects). The enterprises had the opportunity to participate of $120 \mathrm{~h}$ of training and $60 \mathrm{~h}$ of consulting. In 1994 CERTI presents the same program again, where 9 TBEs had the opportunity to participate.

This integration process of TQM with the Incubation Process of TBEs is already allowing to draw some conclusions: 
- The TQM enforces to the entrepreneur the necessity to effectively orient the enterprise to the client and not only to his own technical-scientific interest

- The TQM promote a synergy among the enterprises, stimulating discussions about common problems and the exchange of quality indicators, as well as a healthy competition to verify who is better following the Implementation Plan.

- The TQM develops in the enterprises a critic sense demanding for better services from the Incubator management.

- The Incubation Process may be better evaluated when the TBEs practice the TQM, because the quantity of facts and data that show their evolution, is much larger and richer.

- The TBEs clients appreciate the TQM implementation program and recognize it as a symbol of consciousness and maturity of the enterprises.

- The TQM contributes enormously to accelerate the, so called, classic evolution cycle of an enterprise (represented by Steven C. Brandt) that consists of 5 large phases, separated by 4 big crises [04].

The experience that is involving the 9 TBEs, that are included in the TQM program of the Technological Empresarial Incubator of CERTI is still in an initial phase, consequently hindering more conclusions besides the above already mentioned.

\section{THE GRUCON EXPERIENCE}

The first cooperation program between an European country Institution (RWTH of Aachen, Germany) and the Mechanical Engineering Department of UFSC happened in 1976, having, as one of the objectives, to promote and stimulate the cooperation University-Enterprises in Brazil, using a financial support from GTZ (International Society for Technical Cooperation). GRUCON (Research and Training Group in CAM and Manufacturing Automation) created in 1979 , under the umbrella of this cooperation program, started to work on the development of software in the area of Computer Aided Manufacturing (mainly post-processors for NC machine tools) involving students from Mechanical Engineering and Computer Science Departments. The first post-processor, written for a NC lathe of GRUCON's lab, started a series of other developments, in cooperation with industries, including post-processors implementation and people training.

The natural consequence, of this intense cooperation activities with industries, was the transference of the best high level GRUCON software development people for those enterprises that were investing intensively in a modernization program, including several NC machine-tools for which there was a large demand for post-processors.

For some time these high level people were happy with the type of work they were doing in industry but, afterwards, they figured out that there was no longer a real new challenging task in what they were doing and, besides, they did not have the power to change this situation neither the liberty to choose the type of job they would like to do. The decision, in most cases, was to live the company and to start their own business at their own risk, or to return to the university looking for something else, that could be more interesting.

The alternatives for those returning people in GRUCON were to apply for a postgraduation course or to integrate a R \& D team that could use their professional skills. In both 
cases there were good possibilities to receive a scholarship from the Government Research and Development Agencies. These people were potential candidates to start later on a TBE.

Although the above situation had happened to be the source of a few TBEs formation, the most frequent way has been the under graduate students. When started 17 years ago, GRUCON was dealing basically with Numerical Control, from the point of view of the manufacturing process, involving a few people exclusively from the Mechanical Engineering Department. Afterwards the group has grown and today, there are almost 100 people of different levels (technicians, engineers, system analysts, undergraduate and graduate students, as well as professors) working on different areas, related to Manufacturing Automation. From these people $50 \%$ are undergraduate students. They start in the group, in the bottom of a pyramidal system [05], working under the coordination of engineers or system analysts, that usually are following a research program to obtain their M.Sc. degree. Thus, these under graduate students have the opportunity to be in close contact with research programs since the very beginning of their studies and, some of them, in the last year, are allowed to take some classes in post-graduate level. Besides, some of the projects they get involved are in cooperation with industries, giving them the opportunity to see the results of their work being applied. This procedure give them not only a chance to develop self confidence but also a good idea to deal with enterprises, in order to accumulate experience to become in the future (maybe) an young entrepreneur.

When the work being developed by the students (a software, for instance) has a chance to become a product, they feel much more confident and motivated to improve it, thinking in future trade, what enforces even more the idea of a TBE formation.

In this case, if the professor, that is supervising the project, see a good potential for real future applications and/or to use it in the scope of a M.Sc. or Ph.D. thesis, the student(s) involved are invited to joint the post-graduate course, and/or to submit a proposal to the Development Agencies, in order to get financial support to finish the product development.

In summary, most of the GRUCON people that started their own TBE were:

1) Employees of (usually large size) manufacturing enterprises that did not go through any Incubation Process after living GRUCON.

2) Professionals (mainly Mechanical, Electronic and Computer Engineers) that started in GRUCON (via a scholarship program) as under-grated students and, after getting their degree, remained engaged in a development project, usually supported by industrial cooperation and/or Brazilian Government Scholarships.

3) Professionals (mainly Mechanical, Electronic and Computer Engineers) that started in GRUCON, following the same steps of the above case (2), but improving the development project to present it as a thesis to get his M.Sc. degree.

In the two last cases there were Incubation Process of the TBEs that could use the GRUCON infrastructure to develop and/or improve the product, up to the point where it could become competitive in the market. During this incubation process the entrepreneurs remain as members of the GRUCON team, using any opportunity for marketing their products in all events (exhibitions, fairs, congresses, seminars, speeches, courses, papers, etc.) where GRUCON participates. When the products, developed during the incubation process, starts to be implemented in some potential users, for evaluation purpose, and receive from them the approval for a final implementation, the future entrepreneurs start to prepare the necessary documents for TBE registration. At this moment the enterprises receive special incentives from Brazilian Government via certain tax reduction, in order to help them during the first steps. 
Once they reach a certain level of income, the taxes are progressively increased. As soon as the TBE owners feel confident that the profit perspectives of the market, for their products are good, and they have enough money to rent a place where they could install an initial infrastructure, they leave GRUCON and start to run their business by themselves.

Most of these TBEs keep in close contact, via cooperation projects, with GRUCON, or at least to exchange information about:

a) New business opportunities

b) Scholarships for students that could help the development team of TBEs.

c) High qualified people, with specific skills, to joint the professional team of TBEs.

d) Possibilities for national and international cooperation programs between universities and TBEs.

e) Possibilities to export their products

f) New ways and financial sources to develop joint projects.

\section{CONCLUSIONS}

The results, up to now, achieved by the Incubator created by CERTI can be described as very good due to the following data:

a) Number of consolidated TBEs: 10

b) Number of TBEs installed in the new building of the Incubator at Parktec Alfa: 06

c) Number of Incubated TBEs: 27

d) Mortality rate of TBEs: $10 \%$

(this value is above international standards)

e) Number of selection process executed: 20

f) Estimated TBEs income (1994): 10,000,000.00

g) Published papers about the Incubator: about 100

h) Number of people interested in the Incubator Experience: more than 1500

i) Financial support received from government for IBEs: 64 scholarships

(from which 21 are for Technological Industrial Development)

In Table 01 it is possible to see the description of some characteristics of the TBEs that had been involved in an Incubation Process in GRUCON and are already successfully running their own business. The total annual income of these enterprises is around US $\$ 1,000,000.00$ involving about 50 people, most of them high qualified professionals.

In both, CERTI and GRUCON experiences, the cooperation with other countries (specially Holland, England and Germany in the case of CERTI, and Iberoamerica, via CYTED program as well as European Union, via ECLA, ALFA and KIT projects, in the case of GRUCON), was very important to stablish an international exchange of information about the Incubation Process of TBEs.

The creation of ITIS (table 1) in JUL/91, im Brazil, is a good example of a strong international cooperation among University R \& D groups (DFAC - Universidad de Los Andes, Colombia and GRUCON - Universidade Federal de Santa Catarina, Brazil) as well as large and small size enterprises (IBM, Brazil and INFOTEC, Colombia) hapening during the CYTED program. 
Table 1 Examples of TBEs involved in an Incubation Process in cooperation with GRUCON.

\begin{tabular}{|c|c|c|c|c|c|}
\hline Enterprises & $\begin{array}{c}\text { Created } \\
\text { in }\end{array}$ & $\begin{array}{c}\text { Man Power } \\
1995 \\
\end{array}$ & $\begin{array}{l}N^{0} \text { of imple- } \\
\text { mentations }\end{array}$ & Cooperation & PRODUCTS \&/OR SERVICES \\
\hline ITIS & JUL/91 & $\begin{array}{c}-12- \\
1 \mathrm{M} . \text { Sc. } 1 \text { Eng. } \\
10 \text { Technicians }\end{array}$ & $\begin{array}{l}5 \text { in Brazil } \\
20 \text { abroad }\end{array}$ & $\begin{array}{c}\text { IBM } \\
\text { DFAC } \\
\text { INFOTEC }\end{array}$ & $\begin{array}{c}\text { IXCEL } \\
\text { CAD For fabric } \\
\text { (international) }\end{array}$ \\
\hline AUDACES & JAN/92 & \begin{tabular}{|c|}
$-07-$ \\
05 Comp. Eng. \\
02 Technicians
\end{tabular} & 100 & $\begin{array}{l}\text { ZOCCA } \\
\text { SENAI }\end{array}$ & $\begin{array}{c}\text { CAMSTATION } \\
\text { For injection molding } \\
\text { SECTOR \& INFOCARGA } \\
\text { Automatic nesting 2D/3D } \\
\end{array}$ \\
\hline PROVECTO & APR/92 & \begin{tabular}{|c|}
$05-$ \\
02 Comp. Eng. \\
01 Economist \\
02 Technicians
\end{tabular} & 03 & -- & $\begin{array}{l}\text { Development of Tool Management } \\
\text { Systems for Manufacturing }\end{array}$ \\
\hline EDDROS & APR/95 & $\begin{array}{l}-05- \\
\text { Mech. Eng. } \\
\text { doing M.Sc. }\end{array}$ & 01 & -- & $\begin{array}{c}\text { Comp. Tool Management } \\
\text { System } \\
\text { Implementation }\end{array}$ \\
\hline PAX & JUN/93 & $\begin{array}{c}-05- \\
03 \text { Eng } \\
\text { (1 M.Sc.) }\end{array}$ & 100 & MARBOR & $\begin{array}{c}\text { BORDA } \\
\begin{array}{c}\text { Software for fille manipulation in } \\
\text { embroidery Industry }\end{array}\end{array}$ \\
\hline COMPLEX & 1991 & $\begin{array}{l}-08- \\
3 \text { Comp. Eng. } \\
5 \text { Technicians }\end{array}$ & 150 & $\begin{array}{l}\text { DB } \\
\text { CONSULT } \\
\text { SOMA }\end{array}$ & EVEREST Multimedia software \\
\hline TEIA & OCT/95 & \begin{tabular}{|c|}
$-10-$ \\
07 Comp. Eng. \\
01 journalist \\
02 students
\end{tabular} & 09 & $\begin{array}{l}\text { PRODAU } \\
\text { COMPLEX }\end{array}$ & $\begin{array}{l}\text { Multimedia } \\
\text { Services }\end{array}$ \\
\hline CONASOFT & $\mathrm{DEZ} / 85$ & \begin{tabular}{|c|}
$-03-$ \\
02 Comp. Eng. \\
01 Technicians
\end{tabular} & 50 & ARGENTINA & $\begin{array}{c}\text { Consulting Service \& Development } \\
\text { in CAD/CAM and Manufacturing } \\
\text { Automation }\end{array}$ \\
\hline
\end{tabular}

\section{REFERENCES}

[01] SCHNEIDER, C.A. "Incubadora de Empresas de Base Tecnológica - Um laboratório p/ a Univer. demonstrar a qualidade dos seus produtos." Ciência Hoje, vol. 16/ No 91.

[02] ALLESCH, J. 'Innovation-oriented Regional Policies: A German Experience”. Workshop on Project Columbus Incubator Development Programme. DEC/91, Fpolis, SC.

[03] BOLTON, W.K. "Lessons from the Cambridge Phenomenon" The University of Baltimore Business Review, Vol. 10, N. 2, APR/90, U.K.

[04] SCHNEIDER, C.A.; FIATES, J.E.A. “A Importância da Qualidade Total para o Processo de Incubação de Empresas. Revista TEC BAHIA.

[05] AHRENS, C.H; FERREIRA, A.C. "Cooperação Univer./Empr. na Formação de R. H. e no Desenv. de Pesq. Aplicada, Frente à Modernização do Setor Plásticos", Workshop Ger. no Uso do CAE/CAD/CAM na Fabricação de Moldes. SET/94, SP. 